\title{
Factors influencing the winter haulout behaviour of Weddell seals: consequences for satellite telemetry
}

\author{
Virginia Andrews-Goff ${ }^{1, *}$, Mark A. Hindell ${ }^{1}$, Iain C. Field ${ }^{1,2}$, Kathryn E. Wheatley ${ }^{1,3}$, \\ Jean-Benoît Charrassin ${ }^{4}$
}

${ }^{1}$ Antarctic Wildlife Research Unit, School of Zoology, University of Tasmania, PO Box 252-05, Hobart, Tasmania 7001, Australia

${ }^{2}$ Marine Mammal Research Group, Graduate School for the Environment, Macquarie University, Sydney, New South Wales 2109, Australia

${ }^{3}$ Department of Marine Biology, Texas A\&M University at Galveston, 5007 Avenue U, Galveston, Texas 77553, USA

${ }^{4}$ LOCEAN - UMR 7159, Départements Milieux et Peuplements Aquatiques, Muséum National d'Histoire Naturelle, 43 rue Cuvier, 75231 Paris Cedex 05, France

\begin{abstract}
An understanding of pinniped haulout behaviour can provide information on how animals interact with their environment, their foraging strategies and the behaviour of their prey. For Weddell seals Leptonychotes weddelli, knowledge of haulout patterns and the environmental drivers of haulout is comprehensive for the austral spring and summer, but is poorly described outside this period. Pinniped behaviour is commonly examined using satellite telemetry; however, it is unclear whether the behavioural state of the seal can itself influence data acquisition. We examined haulout behaviour of female Weddell seals in eastern Antarctica over 3 winters (March to August, 2006-2008) using satellite-linked data loggers. Haulout behaviour followed a diel cycle with predominantly nocturnal haulouts. The environmental variables wind speed and temperature were influential on haulout, with seals tending to haul out more in lower winds and at higher temperatures. Haulout duration decreased across the winter, as did the number of satellite uplinks, suggesting that haulout duration played a role in data acquisition. There was no evidence of a decline in tag condition over this period, indicating that the decrease in uplinks was primarily the result of the winter behaviour of the seals. Overall, the number of haulout locations in the data set was over-represented, with more uplinks per hour occurring when the seals were hauled out than when they were at sea. For Weddell seals and other ice seals, tracking data that include haulout locations can bias spatial representations of foraging behaviour (e.g. haulout sites may be mistaken for regions of area-restricted search).
\end{abstract}

KEY WORDS: Weddell seal $\cdot$ Haulout $\cdot$ Winter $\cdot$ Satellite telemetry

Resale or republication not permitted without written consent of the publisher

\section{INTRODUCTION}

In pinnipeds, 'haulout' describes the activity of leaving the water to rest, moult, mate, pup or escape predators (Thomas \& DeMaster 1982, Sato et al. 2003, Bengtson \& Cameron 2004, Mulaudzi et al. 2008). Biologists study haulout patterns for both ecological and applied reasons. From an ecological perspective, the duration and timing of haulouts enable inferences on aspects of a seal's environment, such as prey abundance and movement. For example, krill concentrate at the bottom of the water column during the day, be- coming more dispersed at night; therefore, crabeater seals Lobodon carcinophagus forage more intensively during the day and haul out at night (Burns et al. 2008). If a seal does not haul out for an extended period of time, it may be indicative of an extensive search and therefore infers limited prey availability (e.g. at times of low prey abundance, female fur seals Arctocephalus gazella increase foraging trip duration and activity; Boyd et al. 1994). From an applied perspective, haulout patterns have been studied intensively to gain an understanding of the best time of year to undertake population surveys (Carlini et al. 2006), and of how to 
best implement monitoring and management plans (Cunningham et al. 2009)

In both instances it is also important to know how physical aspects of the environment may influence haulout behaviour; consequently, this is well studied for many species, especially throughout the pupping and moulting seasons (Carlens et al. 2006). Important factors include temperature, wind speed, solar radiation, lunar cycle, cloud cover, tidal state, substrate and ice cover (Trillmich \& Mohren 1981, Schneider \& Payne 1983, Reder et al. 2003, Sato et al. 2003). Further complicating the influence of environmental factors on haulout behaviour are the underlying diel patterns that have been noted in most seal species (Erickson et al. 1989).

Pinniped behaviour, both at sea and hauled out, is increasingly examined via satellite telemetry (e.g. crabeater seal, Burns et al. 2004; Baltic ringed seal Phoca hispida botnica, Harkonen et al. 2008; leopard seal Hydrurga leptonyx, Nordøy et al. 2009). However, the behavioural state may influence data acquisition, as transmission conditions are more favourable when the animals are hauled out or in shallow water (Tougaard et al. 2008). This leads to the potential of more uplinks or uplinks of a higher quality during haulout. In their study of the winter movements of Weddell seals Leptonychotes weddelli, Lake et al. (2006) did not receive locations away from haulout sites. This potential bias may lead to inaccurate biological interpretation of the data received via satellite telemetry such as through the application of movement models (Patterson et al. 2008). The potential for haulout behaviour to affect uplinks in this way is complicated by factors such as battery exhaustion, antenna damage and saltwater switch failure, which can result in decreases in the number and quality of uplinks and ultimately tag failure (Hays et al. 2007).

Here we used satellite telemetry data from a study of the winter foraging ecology of Weddell seals to describe haulout patterns outside the pupping, breeding and moulting period (March to August) at 2 locations in eastern Antarctica over 3 yr. In particular, we examined the diel nature of haulout behaviour and the influence of the physical environment for this particularly harsh period. We then determined how haulout behaviour influences the uplink performance of satellite-linked data loggers.

\section{MATERIALS AND METHODS}

Capture, handling and tag deployment. In total, 20 adult, post-moult female Weddell seals were captured at 2 locations: Dumont d'Urville (DDU; 66 $40^{\prime} \mathrm{S}$, $140^{\circ} 00^{\prime} \mathrm{E}$ ) and Davis, in the Vestfold Hills (68 $33^{\prime} \mathrm{S}$, $\left.78^{\circ} 15^{\prime} \mathrm{E}\right)$, over 3 successive summers: $2006(\mathrm{n}=9)$,
2007 ( $\mathrm{n}=6)$ and 2008 ( $\mathrm{n}=5$; DDU only). The seals were equipped with satellite relay data loggers (SRDLs) with conductivity, temperature and depth function (Sea Mammal Research Unit [SMRU], University of St. Andrews, Scotland). The seals were approached on the ice on foot and temporarily restrained with a head bag or pole net while an intravenous injection of Zoletil ${ }^{\circledR}$ (1:1 mixture of tiletamine and zolazepam) at a dosage of $0.5 \mathrm{mg} \mathrm{kg}^{-1}$ (Wheatley et al. 2006) was administered. A 2-component industrial epoxy was used to attach the SRDL to the head, with the antenna facing forward. The seal was then observed during recovery from anaesthesia and allowed to enter the water when no longer sedated. The 'winter' period for the purposes of this study comprised the months March through to August. Haulout behaviour during this time period is not influenced by pupping or moulting. Pupping begins in the last week of September (V. Andrews-Goff unpubl. data) for DDU and the first week of October for Davis (Lake et al. 1997). Moult has finished by late February in both locations (V. Andrews-Goff unpubl. data), enabling tags to be deployed from March onwards.

The SRDLs were programmed to record dive depth, dive start time, dive duration and post-dive surface interval every $4 \mathrm{~s}$. The tags also recorded the start and end time of each haulout. For each $6 \mathrm{~h}$ period, the tags recorded the percent time that the animal spent hauled out, diving and cruising. The tag recognised a haulout when it had been dry for $10 \mathrm{~min}$, and the haulout ended when the tag was wet for $40 \mathrm{~s}$. During haulout, the tag attempted to uplink to overhead satellites every $1 \mathrm{~min} 20 \mathrm{~s}$ for the first $5 \mathrm{~h}$ and then cycled off for $6 \mathrm{~h}$ and on for $1 \mathrm{~h}$. At all other times, the tag attempted to uplink every $40 \mathrm{~s}$.

General haulout behaviour. The trend in average haulout duration, maximum haulout duration and total haulout duration per seal per month over the winter was examined using a series of linear mixed-effects models in the R package (R Develeopment Core Team) (library nlme, function lme) distributed under the GNU general license (www.r-project.org). Each of these 3 response variables was examined in separate models with the fixed variable month and seal included as a random variable.

To estimate the likelihood of a seal being hauled out at any point in time throughout each month, we calculated the average frequency of haulouts occurring within each hour (i.e. the local hour at which the haulout started and the subsequent hours spanned across its duration). We then expressed this as a percentage of the total number of haulout events occurring within each hour per seal. The mean and 95\% confidence intervals of these averages were then compared on a monthly basis to detect any changes in the patterns of haulout timing throughout the winter. Average sunrise and sunset time for each month at each location was 
calculated using the $\mathrm{R}$ package (library maptools, function crepuscle) so that haulout behaviour could be interpreted in regard to light conditions.

Detection of a diel pattern in haulout. We calculated the number of minutes hauled out for each local hour (0 to 23) per seal. To determine if there was a cyclic pattern in the time spent hauled out, we then used these data (number of minutes hauled out in each hour) to calculate the autocorrelation estimate between lag 0 and each lag thereafter (i.e. the autocorrelation between hour $x$ and hour $x+1$, hour $x$ and hour $x$ +2 and so on) for each seal separately using the acf function (stats package; type = correlation) in the $\mathrm{R}$ package. The acf data for all seals were then combined so that the mean autocorrelation and $95 \%$ confidence interval at each lag could be calculated.

Environmental influences on haulout behaviour. To examine the influence of weather on haulout, we fitted a series of generalised linear mixed-effect models (GLMMs) to the data using the lmer function in the $\mathrm{R}$ package. GLMMs are linear models that include fixed and random effects. The fixed effects considered for the models were: wind speed, air temperature, wind chill (Edholm \& Lewis 1964) and ice concentration. Individual was included as a random effect. Weather data were sourced from the Australian Government Bureau of Meteorology and were collected for Davis (Vestfold Hills) and the DDU station. For all seals and years, the average maximum distance travelled from the base was $68 \mathrm{~km}$ at Davis and $50 \mathrm{~km}$ at DDU, so we assumed that the weather at the stations was similar to that experienced by the seals. Ice concentration was extracted at all locations provided by Argos (including haulout and at-sea locations) from the daily remote sensing sea ice concentration maps $(6.25 \mathrm{~km}$ grid resolution) retrieved from the Advanced Microwave Scanning Radiometer-Earth Observing System (AMSR-E; Institut für Umweltphysik Universität Bremen, www. iup.physik.uni-bremen.de:8084/amsr/amsre.html).

The model's response variable, haulout, was adjusted to be a binary response (i.e. hauled out or not hauled out) per local hour (DDU = UTC $+10 \mathrm{~h}$, Vestfold Hills $=\mathrm{UTC}+7 \mathrm{~h}$ ) to help normalise the data. Wind speed was log-transformed to correct for a non-Gaussian distribution. Each model contained a binomial error distribution with a logit link. The models were run 100 times on a $10 \%$ sub-sample of the data to minimise the temporal auto-correlation within the data.

The model set comprised all of the variables in logical combinations including additive and interaction terms. The best of these models were chosen using an information-theoretic model selection procedure, which uses deviance as a measure of fit and includes a term to penalise more complex models that often fit the data better, but increase the uncertainty in each vari- able as well as the variance in predictions. We chose to use the change in Bayesian Information Criterion $(\delta \mathrm{BIC})$ to determine the magnitude of difference between models as opposed to Akaike's Information Criterion (AIC), which is known to have a bias in large sample sizes. The top-ranking model was chosen as the best fit model of the models available if $\delta \mathrm{BIC}$ was greater than 2 .

Effect of haulout behaviour on satellite uplinks. We examined diagnostic data supplied by Argos to determine antenna, battery and saltwater switch damage to assess how tag condition may influence the number of uplinks received and therefore differentiate between the influence of haulout on uplinks versus the influence of tag condition on uplinks. Following the methods of Hays et al. (2007) and Lea et al. (2009) we compared the actual number of uplinks achieved for each tag to the expected number of uplinks (80000) to ascertain if the relayed number of uplinks was within $90 \%$ of the expected number of uplinks. If so, the battery was assumed to have drained. The running averages describing the driest condition of the saltwater switch were examined to detect a progressive reduction towards 50, indicating the build-up of bio-fouling, and the number of times the wet-dry sensor failed was examined to determine saltwater switch failure. Finally, the best level reading was examined to detect any erratic or steep decline towards the end of the tag's life, indicating antenna failure.

To determine whether haulout behaviour influenced the number of uplinks, we quantified the time spent hauled out per seal per month and the total uplinks per seal per month with a linear mixed model (nlme package) in the $\mathrm{R}$ package. Number of uplinks was the response variable modelled against the fixed variable, total haulout duration, with seal as the random variable.

To determine the conditions under which an uplink was unlikely, we used the $6 \mathrm{~h}$ behaviour summaries, retaining only days in which all 4 summaries were complete so that each seal's daily activities could be represented as the proportion of time spent hauled out and the proportion of time at sea (time spent diving + time spent cruising). We then determined whether an uplink did or did not occur in this daily period and applied a GLMM to the data in the R package (lmer function, binomial error distribution and logit link). The binomial response variable, uplink, was modelled against the fixed variable time spent at sea with seal as a random variable.

To examine whether haulout behaviour has the potential to lead to spatial misinterpretation of the data (i.e. whether haulout locations are over- or underrepresented in the data), we determined how many uplinks overall corresponded to times at which a seal 
was hauled out and times at which it was at sea. We then determined the time spent at sea and hauled out per seal per month, which enabled the calculation of number of uplinks per hour when at sea and number of uplinks per hour when hauled out on a monthly basis per seal. These monthly values were averaged for each seal, resulting in a value of uplinks per hour hauled out and uplinks per hour at sea for the entire winter period for each seal. These values were then compared using a paired $t$-test in the $\mathrm{R}$ package to determine whether the number of uplinks occurring when hauled out differed significantly from the number of uplinks occurring when at sea.

\section{RESULTS}

Of the 20 tags deployed, data from 5 tags were excluded from this study as they did not provide an adequate representation of the winter period. Deployment details for the 15 tags included in this study are given in Table 1.

\section{General haulout behaviour}

Over the 3 yr of this study, we recorded 2074 haulout events from 15 seals, averaging $3.9 \pm 0.1 \mathrm{~h}($ mean $\pm \mathrm{SE})$ in duration and ranging from 0.15 to $23 \mathrm{~h}$. The average interval between haulouts was $24.44 \pm 0.59 \mathrm{~h}$. Sixty-two percent of intervals were less than $24 \mathrm{~h}$; however, intervals were as long as $8 \mathrm{~d}$. Seals spent on average $20 \pm 0.5 \%$ of their time hauled out.

Total time hauled out each month for each seal decreased from March $(150 \pm 15.7 \mathrm{~h})$ to September $\left(86 \pm 11 \mathrm{~h} ;\right.$ ANOVA $F_{1,57}=37.42, \mathrm{p}<0.0001 ;$ Table 2$)$. However, the average and maximum haulout duration did not differ significantly with month (average haulout duration ANOVA $F_{1,57}=0.33$, $\mathrm{p}=0.57$; maximum haulout duration ANOVA $F_{1,57}=3.06, p=0.085$ ), indicating a decline in number of haulouts per seal per month (Table 2).

In March, there was a peak in haulout frequency at approximately 18:00 hi however, from April to August, this pattern shifted to a peak in haulout frequency in the early morning hours (approximately 02:00 to 04:00 h) and a minimum at approximately 12:00 to 18:00 h (Fig. 1). Examination of average time of sunrise and sunset showed that for March, the peak haulout period occurred during the day, whereas from April to August, the peak haulout period corresponded to night (Fig. 1).

\section{Diel patterns in haulout behaviour}

The mean autocorrelation for all seals (Fig. 2) indicated decreasing significance of autocorrelation between lag 0 and each lag thereafter (with significant autocorrelation being indicated by any bar above or below the dotted line). Mean autocorrelation peaked again at lag 24. On an individual basis, 11 of the 15 seals demonstrated a significant autocorrelation at lag 24. The 4 other seals demonstrated a peak in autocorrelation at lags 25, 25, 26 and 27, respectively. Overall, the mean autocorrelation plot (Fig. 2) indicates that it is highly likely that the behaviour exhibited at lag 0 will be exhibited again $24 \mathrm{~h}$ later. 

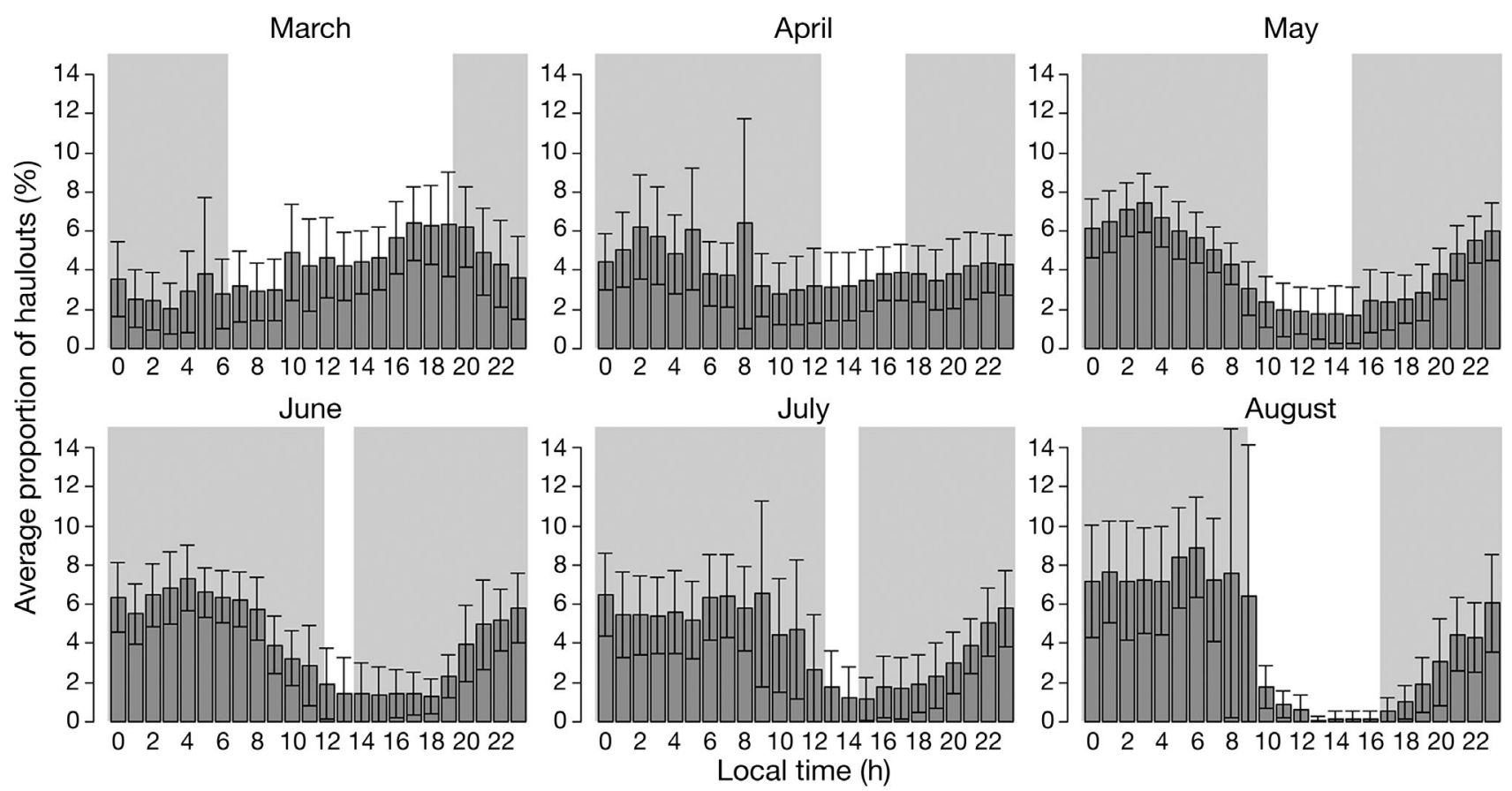

Fig. 1. Leptonychotes weddelli. Likelihood of a seal being hauled out at each local hour per month expressed as a percentage of the total number of haulout events occurring within each hour per seal for the months March through to August. 95\% confidence intervals are shown. Shaded areas: nocturnal periods; unshaded areas: diurnal periods

\section{Influence of physical variables on haulout}

The top model used wind speed and temperature (Table 3) to explain whether a seal was hauled out. In 70 of 100 iterations, log wind speed and temperature were the top model $; 73 \%$ of the time the $\delta$ BIC was $\geq 2$, with a mean value of $3.20 \pm 0.41$ (mean $\pm \mathrm{SE}$ ). Average wind speed when hauled out $\left(14.4 \pm 9.91 \mathrm{~m} \mathrm{~s}^{-1}\right)$ was $3 \mathrm{~m} \mathrm{~s}^{-1}$ lower than wind speeds when not hauled out (17.4 \pm $\left.12.4 \mathrm{~m} \mathrm{~s}^{-1}\right)$. Temperatures at haulout $\left(-12.8 \pm 6.20^{\circ} \mathrm{C}\right)$ were around $0.33^{\circ} \mathrm{C}$ higher than temperatures when not hauled out $\left(-13.1 \pm 6.37^{\circ} \mathrm{C}\right)$. The warmest temperatures occurred in March $\left(-8.01 \pm 0.14^{\circ} \mathrm{C}\right.$; monthly average of temperature across sites) followed by a decline in temperature to July $\left(-16.4 \pm 0.21^{\circ} \mathrm{C}\right)$ after which there was an increase in temperature in August $\left(-15.1 \pm 0.2^{\circ} \mathrm{C}\right.$; Fig. 3a). Wind speed was variable across months $(18 \pm$ $0.43 \mathrm{~m} \mathrm{~s}^{-1}$; monthly average of wind speed across sites), with May experiencing the strongest winds and July the lightest (15.2 $\pm 0.4 \mathrm{~m} \mathrm{~s}^{-1}$; Fig. 3b).

\section{Effect of haulout behaviour on satellite uplinks}

Failure due to saltwater switch failure or battery exhaustion was not detected in any of the 15 tags. For 2 tags, failure could be attributed to antenna failure evident within approximately the last $25 \mathrm{~d}$ of the tags'

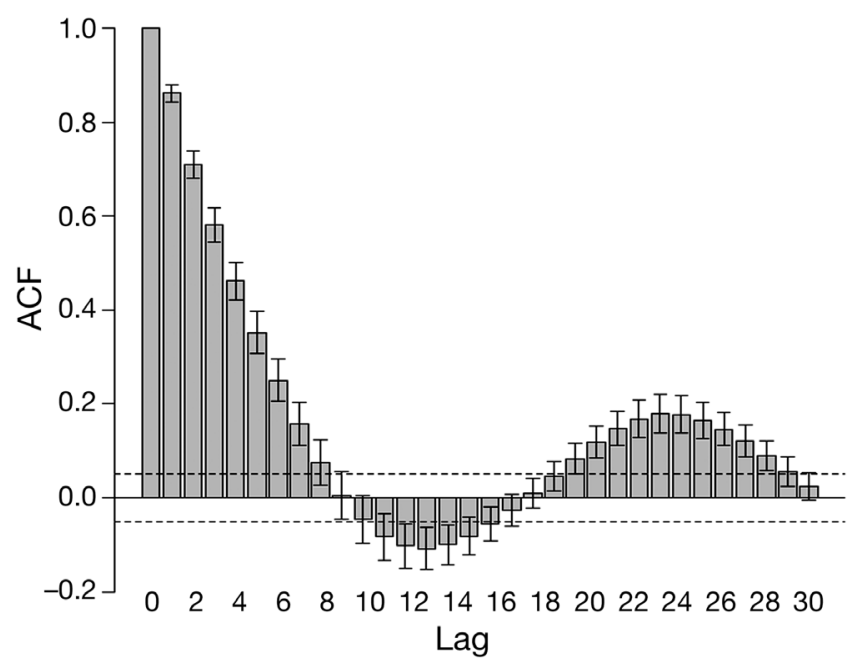

Fig. 2. Leptonychotes weddelli. Mean autocorrelation function (ACF) plot of haulout behaviour for all seals, showing 95\% confidence intervals. Any bar reaching above the dotted line is correlated with lag 0 (lags in $\mathrm{h}$ ). Correlation declines towards lag 12 and peaks again at around lag 24, indicating a diel cycle in haulout behaviour

life. For both tags, this corresponded to the month of October, which was not included in the analyses, as it was outside the March to August period of interest.

In total, there were 21944 uplinks over the months of March to August for the 15 seals (an average \pm SE of 
Table 3. Results from 100 iterations of the generalised linear mixed-effect model: the number of times the model was best model (Frequency) and variables comprising that model

\begin{tabular}{|cl|}
\hline Frequency & Variables \\
\hline 70 & Log wind speed + temperature \\
14 & Log wind speed + temperature + log wind \\
& speed $\times$ temperature \\
13 & Log wind speed \\
1 & Ice concentration + log wind speed + \\
& temperature \\
1 & Ice concentration + log wind speed + \\
& temperature $+\log$ wind speed $\times$ temperature
\end{tabular}

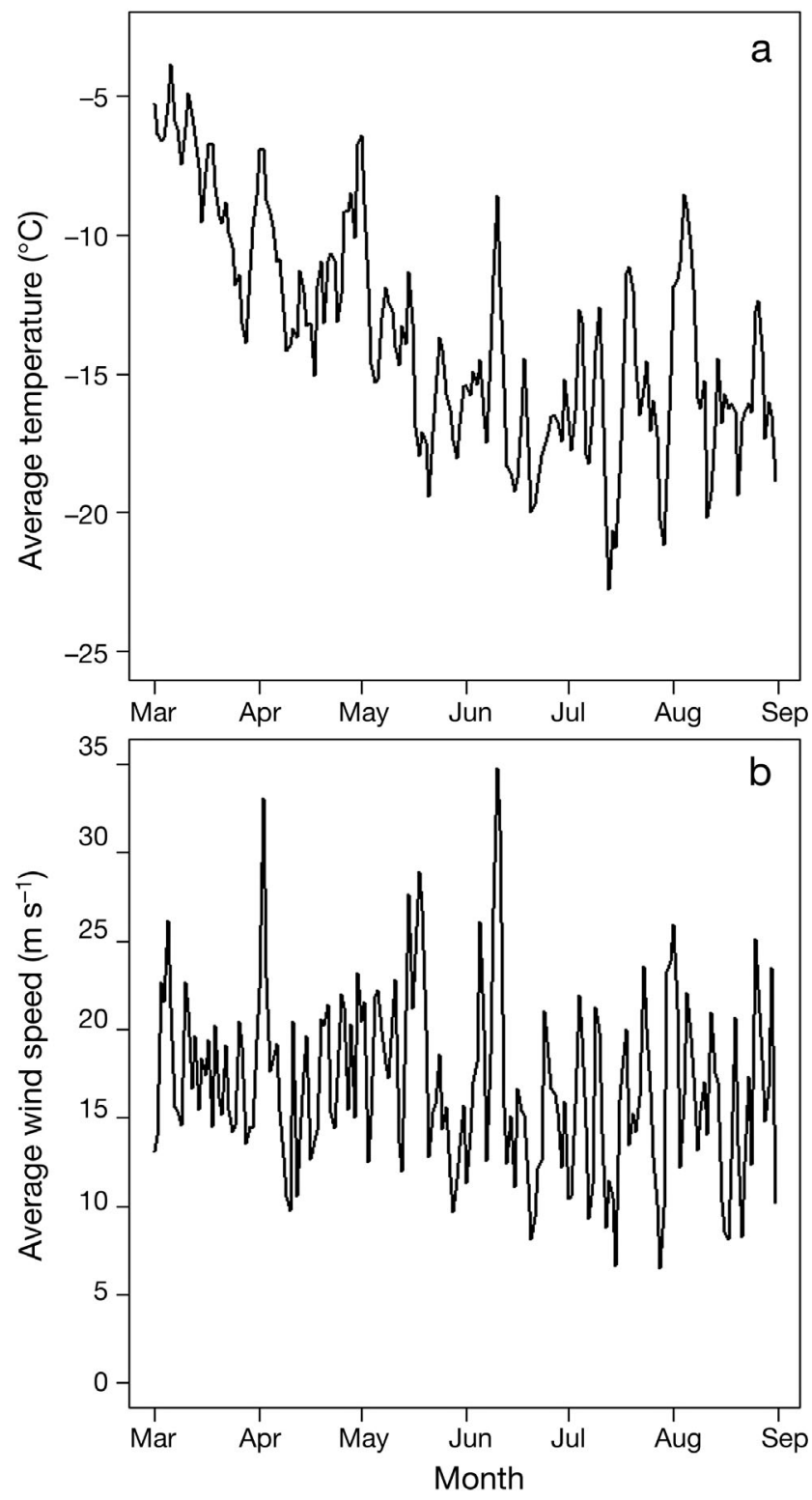

Fig. 3. Average daily (a) temperature and (b) wind speed for Dumont d'Urville and the Vestfold Hills across the study period
$1462 \pm 311$ uplinks per seal). The average number of uplinks per seals per month decreased from March $(422 \pm 63)$ to August $\left(260 \pm 108\right.$; ANOVA $F_{1,56}=29.65$, $\mathrm{p}<0.0001$; Fig. 4a).

A longer time spent hauled out per month resulted in a greater number of uplinks (ANOVA $F_{1,56}=59.69, \mathrm{p}<$ 0.0001, Fig. 4b). The longest total time spent hauled out occurred in March $(150 \pm 15.7 \mathrm{~h})$, which corresponded to the month of greatest average number of uplinks per seal $(422 \pm 63)$ as opposed to the month of July, in which total time spent hauled out was lowest $(81 \pm 10.7 \mathrm{~h})$ as were the average number of uplinks per seal (229 \pm 71.9). Therefore, fewer uplinks occurred as total haulout
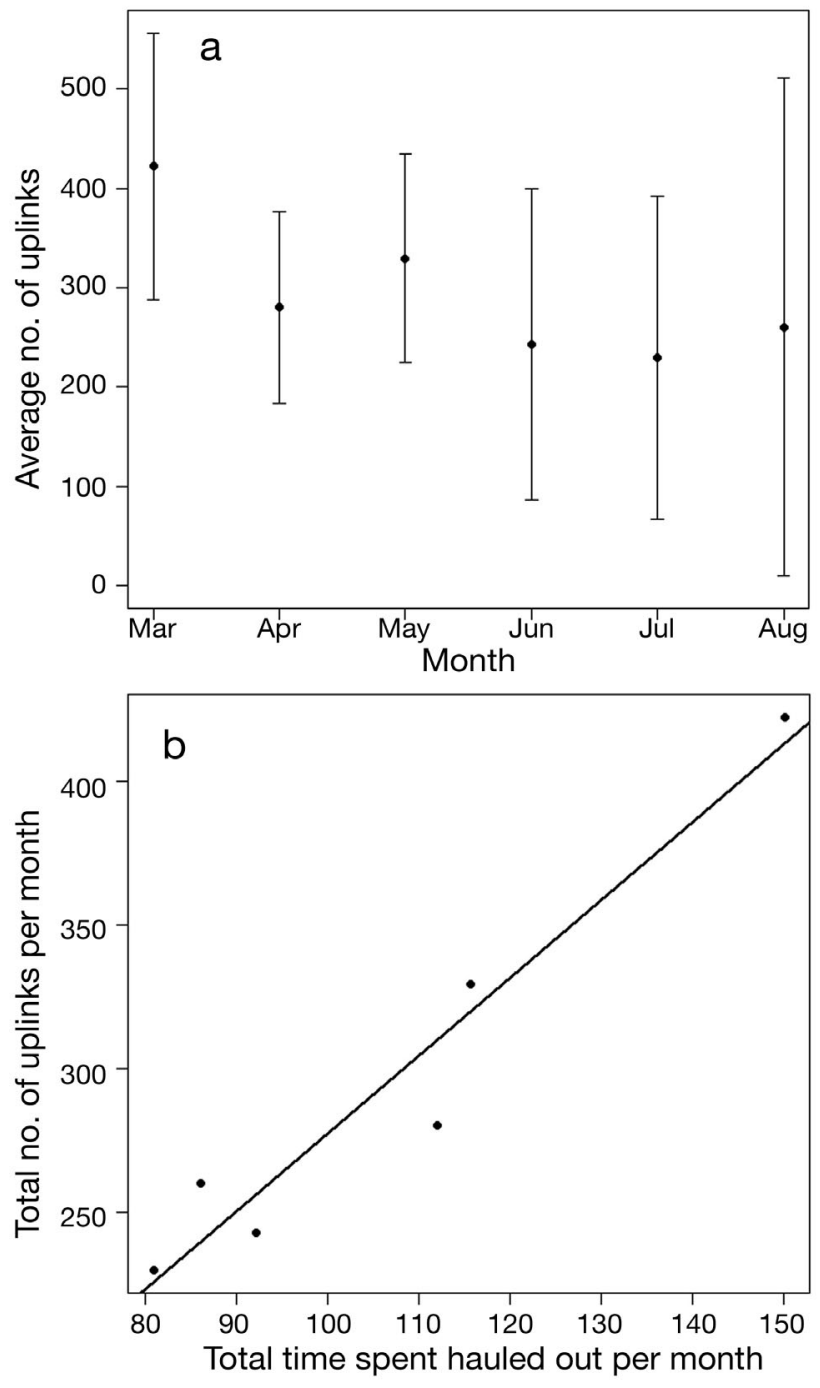

Fig. 4. Leptonychotes weddelli. (a) Average number of uplinks per seal per month with $95 \%$ confidence intervals demonstrating a decline in uplinks as the study period progressed (ANOVA $F_{1,56}=29.65, \mathrm{p}<0.0001$ ). (b) Average total haulout duration per seal per month in relation to the average number of uplinks per seal per month (linear regression $F_{1,4}=57.28$, $\mathrm{p}=0.002$, adj. $\mathrm{R}^{2}=0.92$ ) 
duration decreased. An uplink was most likely on days when the seal spent less than $81 \pm 0.44 \%$ of its time at sea, and least likely when it spent more than $95.8 \pm$ $1.35 \%$ of the day at sea $(\mathrm{BIC}=417.1, \log$ likelihood $=$ -197.5 , deviance $=395, p=0.0000017)$. More uplinks occurred during haulouts $\left(0.67\right.$ uplinks $\left.\mathrm{h}^{-1}\right)$ than when at sea (0.35 uplinks h${ }^{-1} ; t=2.69, \mathrm{p}=0.02$ [2-tailed], $\mathrm{df}=10$; Table 4).

\section{DISCUSSION}

\section{Winter haulout behaviour}

Few aspects of the winter behaviour of Weddell seals have been described. However, many studies have described haulout throughout the austral spring and summer, reporting haulout as a diurnal event with a peak in mid- to late afternoon (Smith 1965, Stirling 1969, Siniff et al. 1971, Thomas \& DeMaster 1983, Lake et al. 1997, Sato et al. 2003). Only Kooyman (1975) noted haulout patterns outside of this period which he found to be nocturnal. With the exception of the month of March, we also detected a tendency to haul out nocturnally throughout the 'winter' period. For Weddell seals, it seems there is a switch in haulout behaviour between the austral spring and summer period to the autumn and winter period. We also detected a diel pattern of haulout, indicating that each haulout occurs at a similar time among the seals. The timing of haulout, i.e. whether it is nocturnal or diurnal, whether it occurs at a regular or irregular time or whether it is protracted or short, has the potential to infer information on the activities of the seal (e.g. pupping), the foraging environment (e.g. prey availability) and environmental conditions (e.g. temperature).

Haulout behaviour was greatly influenced by biological events occurring throughout the austral spring and summer. Haulout behaviour is initially modified as Weddell pups are born and nursed on the ice (Thomas \& DeMaster 1983) in late September to early October for DDU (V. Andrews-Goff unpubl. data) and the Vestfold Hills (Lake et al. 1997). Then during moult, which may start as early as January and is usually finished by March (Andrews-Goff unpubl. data), the peak in haulout at midafternoon when solar radiation is at its greatest allows for a more efficient moult as skin temperature is increased (Feltz \& Fay 1966, Schneider \& Payne 1983, Boily 1995). Nocturnal haulout as a general behaviour has been described for a number of northern hemisphere seals, including the Saimaa seal Phoca hispida saimensis (Kunnasranta et al. 2002), the Baltic grey seal Halichoerus grypus (Sjöberg et al. 1995), captive harp seals Pagophilus groenlandicus (Moulton et al. 2000) and Baltic ringed seals Phoca hispida botnica (Harkonen et al. 2008), and in these cases, was considered a response to prey behaviour, disturbance and weather.

A switch from diurnal (summer) to nocturnal haulout behaviour (winter) has also been described for crabeater seals (Burns et al. 2004) along the western Antarctic Peninsula. This switch reflects prey behaviour throughout the winter period, as the seals concentrate foraging effort during the day and at depths close to the bottom to access prey (zooplankton) and haul out during the night when foraging opportunities are more limited due to a more dispersed distribution of their prey. The winter prey of Weddell seals, which includes Pleuragramma antarcticum, benthic fish and prawns (Lake et al. 2003), may feed on zooplankton, and therefore be aggregated during the day. If this were the case, it would be more profitable for Weddell seals to concentrate foraging effort during the day.

While the timing of haulout may be determined by prey behaviour, it can also be due to the foraging strategies of the predator. Weddell seals' eyes are modified to function in low light conditions, with a high degree of summation (Pütter 1903) and only rod-shaped receptors (Landau \& Dawson 1970). Weddell seals use the underice surface for backlighting when foraging (Davis et al. 1999), indicating that vision is important to these predators. Assuming vision is vital to the successful foraging of Weddell seals, periods of low light availability would adversely impact foraging, and therefore the seals would be more likely to spend these periods doing other activities such as hauling out. We hypothesise

Table 4. Leptonychotes weddelli. Time spent hauled out as a percentage of total time available each month, percentage of uplinks occurring at haulout and at sea in relation to total number of uplinks, and number of uplinks per hour and seal month when hauled out and when at sea. All values are means \pm SE

\begin{tabular}{|c|c|c|c|c|c|}
\hline \multirow{2}{*}{ Month } & \multirow{2}{*}{$\begin{array}{c}\text { Time hauled out } \\
(\%)\end{array}$} & \multirow[b]{2}{*}{ at haulout $(\%)$} & \multicolumn{2}{|c|}{ No. of uplinks } & \multirow[b]{2}{*}{$\mathrm{h}^{-1}$ at sea } \\
\hline & & & at sea $(\%)$ & $\mathrm{h}^{-1}$ at haulout & \\
\hline March & $20.2 \pm 0.02$ & $16.6 \pm 2.12$ & $83.4 \pm 7.2$ & $0.52 \pm 0.08$ & $0.66 \pm 0.07$ \\
\hline April & $15.6 \pm 1.33$ & $29.8 \pm 6.44$ & $70.2 \pm 7.82$ & $0.72 \pm 0.14$ & $0.32 \pm 0.04$ \\
\hline May & $15.6 \pm 1.17$ & $27.3 \pm 5.1$ & $72.7 \pm 14.5$ & $0.86 \pm 0.22$ & $0.34 \pm 0.07$ \\
\hline June & $12.8 \pm 1.22$ & $24.7 \pm 7.53$ & $75.3 \pm 13.4$ & $0.59 \pm 0.11$ & $0.27 \pm 0.05$ \\
\hline July & $10.9 \pm 1.45$ & $20.5 \pm 7.45$ & $79.5 \pm 16.6$ & $0.52 \pm 0.18$ & $0.21 \pm 0.04$ \\
\hline August & $11.6 \pm 1.48$ & $23.6 \pm 9.5$ & $76.4 \pm 25.7$ & $0.64 \pm 0.25$ & $0.22 \pm 0.08$ \\
\hline
\end{tabular}


that for these visual predators, there is a distinct advantage to hunting during the time periods of highest light throughout the light-limited winter months. Concurrently, these periods of highest light in the winter may be associated with certain prey behaviours (as discussed for zooplankton by Burns et al. 2004) that increase the potential for foraging success.

Physical factors related to thermoregulation also influence the winter haulout behaviour of Weddell seals, which are more likely to haul out under conditions of low wind speed and relatively higher temperature. This suggests that the 'wind chill' effect (the combination of wind speed and temperature) influences haulout. However, the wind chill calculation (Edholm \& Lewis 1964) we included in the GLMM was derived to describe the relationship between wind speed, temperature and heat loss in humans living in polar regions. Consequently, wind chill was not correlated with haulout and therefore was not an appropriate index to describe the combined effect of wind speed and temperature on Weddell seals. Haulout under conditions of higher temperature and lower wind speed has been noted previously for the austral spring and summer (Cornet \& Jouventin 1980, Lake et al. 1997, Sato et al. 2003); however, in winter, the warmest temperatures are far colder than summer temperatures. Weddell seals have a thick subcutaneous blubber layer that together with peripheral vasoconstriction allows them to remain homeothermic in cold water (Boily 1995) and thermoneutral to at least $-7^{\circ} \mathrm{C}$ (Noren et al. 2008). Vasoconstriction results in a lack of nutrients and oxygen reaching the epidermis, and epidermal metabolism is slowed or inhibited. Epidermal maintenance most notably occurs during summer (moult) when the thermal requirements of the epidermis can be satisfied on land (in air) where the heat flux is 25 times lower than in water of the same temperature (Noren et al. 2008). Promoting blood flow to the epidermis may be an advantage of hauling out during winter under conditions of low wind speed and high temperature.

\section{Effect of haulout behaviour on satellite uplinks}

Ideal conditions for uplink to overhead satellites are often sustained during haulout as compared to intermittent opportunities when regularly diving at sea. For tagged animals that inhabit fast ice, uplinks may be limited further by the lack of open water through which the tag can be lifted to the surface to uplink to overhead satellites. Therefore, haulout behaviour has the potential to influence how many uplinks occur and how the collected data are interpreted, due to the potential for haulout locations to be over-represented within the data set (Lake et al. 2006).
Total time hauled out each month declined as winter progressed, as did the number of uplinks per month. This may be a direct relationship moderated by physical factors such as wind chill, which increases as winter temperature continues to decline and wind speed increases (and therefore results in fewer or shorter haulouts). In this case, haulout behaviour influences the number of uplinks due to the positive relationship between haulout duration and number of uplinks. However, it is possible that this decline in uplinks may also be influenced by tag condition. Saltwater switch failure, which is often due to bio-fouling of the saltwater switch, may account for a reduction in uplinks (Hays et al. 2007) but was not detected for the tags deployed in this study. There is considerable potential for antenna damage as the antenna is routinely knocked and forced through ice when Weddell seals, breathe and haul out through ice holes or ice cracks in the winter. We detected antenna damage for 2 tags after $200 \mathrm{~d}$ of deployment, indicating that the antennas can withstand the rigours of the Antarctic winter and did not influence the occurrence of uplinks. No tag reached a point where it had exhausted its battery, as indicated by the number of uplinks obtained for each tag. The battery itself can operate throughout a wide range of temperatures $\left(85^{\circ} \mathrm{C}\right.$ to $-60^{\circ} \mathrm{C}$; the specification sheet can be found at www.saftbatteries.com/Produit_LSH_cell_range_303_8/ Language/en-US/Default.aspx\#DL2); therefore, the cold conditions under which it operates should not influence battery life or function. At low temperatures, voltage can collapse, causing the tag to reset; however, SMRU SRDLs protect themselves by suppressing transmissions below $-15^{\circ} \mathrm{C}$. This may contribute to the decreased number of uplinks throughout the months of May, June, July and August in which temperatures lower than $-15^{\circ} \mathrm{C}$ are routinely experienced (Fig. 3a). Haulout duration decreased across this same period; therefore, differentiating whether a decrease in uplinks is due to transmission suppression or to haulout behaviour is virtually impossible. However, our data indicate that Weddell seals tend to haul out in warmer conditions, which makes it likely that uplinks will occur during haulout. When uplinks occur at sea, the tag comes to the surface exiting at a water temperature of around $-1.8^{\circ} \mathrm{C}$. Once again, it is likely that uplinks will occur initially before cooling to the ambient temperature.

The satellite pass schedule may also influence a tag's potential to uplink to overhead satellites. If the majority of satellites pass nocturnally when haulout is more likely, there is greater potential for an uplink. Unfortunately, the historic satellite pass schedule is not available, although there are currently 6 satellites that pass approximately 10 times $\mathrm{d}^{-1}$ (i.e. approximately 60 passes $\mathrm{d}^{-1}$ ), and each pass can range from just a few minutes to $15 \mathrm{~min}$ (CLS Argos). 
Lake et al. (2006) suggested that even though head attachment of transmitters is the optimal method to ensure locations collected in the water as well as hauled out, this attachment may result in the inability to use small breathing holes, undermine networks of breathing sites and winter foraging behaviour, and ultimately affect survivorship. However, our study demonstrated that head attachments did not affect the ability of seals to access breathing holes throughout the winter months: seals spent $80 \%$ of their time at sea, and $77 \%$ of all locations received were at sea where the opportunity for uplinks presumably occurred when the seal accessed a hole, crack or open water to breathe. In addition, tag deployment duration (Table 1) and the available resight data for DDU indicate that this method of attachment does not affect survivorship (Vestfold Hills resight data not available). Of the 12 seals tagged at DDU in 2007 and 2008 ( 7 of which were included in this study), only 2 remain unaccounted for. Both of these seals are assumed to have been equipped with faulty tags, as 1 tag operated sub-optimally (few uplinks of low quality) for 2 mo before failure, and the other tag failed within the first week of deployment.

There is potential for location information collected by the tags to be biased to haulout locations, as uplinks are more likely when a seal spends less than $81 \%$ of its day in the water. Weddell seals do not necessarily haul out next to their foraging site, and attempts to detect foraging areas may be influenced by a predominance of haulout locations (Lake et al. 2006). Our analyses confirm that there is a bias in the number of uplinks occurring at haulout ( 0.67 uplinks $\mathrm{h}^{-1}$ as opposed to 0.35 uplinks $\mathrm{h}^{-1}$ when not hauled out), and therefore there is over-representation of haulout locations within this data set. Tracking data are often used to describe foraging behaviour and identify important foraging locations through techniques that assess the amount of time spent within a certain area (e.g. area-restricted search). For ice seals such as Weddell seals that do not return to a central haulout site, tracking data contain locations when hauled out and locations when at sea. This contrasts to the tracks of other seals, generally described as central place foragers, that return to a central haulout site. For a central place forager, each time at sea can be regarded as a 'trip' and the track can be broken down into multiple 'trips' comprising locations at sea. When a seal is hauled out, it is not foraging, yet these over-represented haulout locations are often included when assessing important foraging areas for ice seals. Therefore, if tracking data are used to identify important foraging sites and describe general foraging behaviour of ice seals that frequently haul out, there is the potential for the results to be misleading. We can go some way to addressing this overrepresentation of haulout locations in the data set quite easily by simply differentiating between haulout locations and at-sea locations and then modifying the analyses accordingly. For example, haulout locations may be removed completely when constructing the track to identify foraging behaviour. When identifying area-restricted search through any of the multitude of methods available, haulout locations can initially be assigned to a behavioural class such as 'rest' or 'haulout' and therefore excluded from being classed as a 'search' behaviour.

\section{CONCLUSIONS}

For the months of April through to August, Weddell seal haulout was predominantly nocturnal, and each haulout occurred at a similar time. Total monthly haulout duration declined across the same period. Both temperature and wind speed influenced the timing of haulout, with seals more likely to haul out under conditions of low wind and high temperature. Therefore, it is likely that the timing of haulout is partly governed by thermoregulatory requirements. Other potential hypotheses to explain timing of haulout from March to August involve behaviour of both predator and prey.

The number of uplinks per month declined across the March to August time period relative to the decline in haulout duration per month, indicating that haulout duration and the number of haulouts influence the number of uplinks. An uplink was more likely when a seal spent less than $81 \%$ of its day at sea. The number of uplinks $\mathrm{h}^{-1}$ when hauled out was greater than the number of uplinks $\mathrm{h}^{-1}$ when at sea, leading to an overrepresentation of haulout locations within this Weddell seal tracking data set. For any ice seal that routinely hauls out, there is the potential for this same bias towards a predominance of haulout locations, which may lead to inaccurate interpretation of the data. Analyses need to be modified to address this.

Acknowledgements. We thank S. Blanc, A. Jacquet-Chaboisson, E. Antoine and all volunteers from Dumont d'Urville who assisted in the field. We also thank J. Horsburgh, P. Tucak, L. Clark, J. Kingston and all volunteers who assisted in the field at the Vestfold Hills. We thank all reviewers for providing invaluable comments and suggestions to improve this manuscript. This study was supported by an Australian Antarctic Science grant (AAS project 2794), and the program TerreOcéan-Surface Continentale-Atmosphère of the Centre National d'Etudes Spatiales (TOSCA-CNES). We thank the Australian Antarctic Division, Institut Polaire Français Paul Emile Victor (IPEV programs 109 and 394) and Terres Australes et Antarctiques Françaises (TAAF) for providing logistical support and clothing. We are grateful to C. A. Bost and C. Guinet for their support. Fieldwork and data collection were undertaken with approval from the University of Tasmania Animal Ethics Committee (permit A8523), and from IPEV and 
TAAF Animal Ethics Committees. All animals in this study were cared for according to these guidelines. V.A.-G.was supported by a Tasmanian Graduate Research Scholarship.

\section{LITERATURE CITED}

Bengtson JL, Cameron MF (2004) Seasonal haulout patterns of crabeater seals (Lobodon carcinophaga). Polar Biol 27: 344-349

Boily P (1995) Theoretical heat flux in water and habitat selection of phocid seals and beluga whales during the annual molt. J Theor Biol 172:235-244

Boyd IL, Arnould JPY, Barton T, Croxall JP (1994) Foraging behaviour of Antarctic fur seals during periods of contrasting prey abundance. J Anim Ecol 63:703-713

Burns JM, Costa DP, Fedak MA, Hindell MA and others (2004) Winter habitat use and foraging behavior of crabeater seals along the Western Antarctic Peninsula. DeepSea Res II 51:2279-2303

- Burns JM, Hindell MA, Bradshaw CJA, Costa DP (2008) Finescale habitat selection of crabeater seals as determined by diving behavior. Deep-Sea Res II 55:500-514

Carlens H, Lydersen C, Krafft BA, Kovacs KM (2006) Spring haul-out behaviour of ringed seals (Pusa hispida) in Kongsfjorden, Svalbard. Mar Mamm Sci 22:379-393

Carlini AR, Daneri GA, Casaux R, Márquez MEI (2006) Haulout pattern of itinerant male Antarctic fur seals (Arctocephalus gazella) at Laurie Island, South Orkney Islands. Polar Res 25:139-144

Cornet A, Jouventin P (1980) Le phoque de Weddell (Leptonychotes weddelli) à Pointe Géologie et sa plasticité sociale. Mammalia 44:497-521

Cunningham L, Baxter JM, Boyd IL, Duck CD, Lonergan M, Moss SE, McConnell B (2009) Harbour seal movements and haul-out patterns: implications for monitoring and management. Aquat Conserv 19:398-407

Davis RW, Fuiman LA, Williams TM, Collier SO and others (1999) Hunting behaviour of a marine mammal beneath the Arctic fast ice. Science 283:993-996

Edholm OG, Lewis HE (1964) Terrestrial animals in the cold: man in polar regions. In: Dill DB, Adolph EF, Wilbur CG (eds) Adaptation to the environment. American Physiological Society, Washington, DC, p 435-499

Erickson AW, Bledsoe LJ, Hanson MB (1989) Bootstrap correction for diurnal activity cycle in census data for Antarctic seals. Mar Mamm Sci 5:29-56

- Feltz E, Fay F (1966) Thermal requirements in vitro of epidermal cells from seals. Cryobiology 3:261-264

Harkonen T, Jüssi M, Jüssi I, Verevkin M, Dmitrieva L, Helle E, Sagitov R, Harding KC (2008) Seasonal activity budget of adult Baltic ringed seals. PLoS ONE 3:e2006

- Hays GC, Bradshaw CJA, James MC, Lovell P, Sims DW (2007) Why do Argos satellite tags deployed on marine animals stop transmitting? J Exp Mar Biol Ecol 349:52-60

Kooyman GL (1975) A comparison between day and night diving in the Weddell seal. J Mammal 56:563-574

Kunnasranta M, Hyavarinen H, Hakkinen J, Koselka JT (2002) Dive types and circadian behaviour patterns of Saimaa ringed seals Phoca hispida saimensis during the open water season. Acta Theriol (Warsz) 47:63-72

> Lake S, Burton H, Hindell M (1997) Influence of time of day and month on Weddell seal haul-out patterns at the Vestfold Hills, Antarctica. Polar Biol 18:319-324

Lake S, Burton H, van den Hoff J (2003) Regional, temporal and fine-scale spatial variation in Weddell seal diet at four coastal locations in east Antarctica. Mar Ecol Prog Ser 254:293-305

Editorial responsibility: Daniel Costa,

Santa Cruz, California, USA
Lake S, Burton H, Wotherspoon S (2006) Movements of adult female Weddell seals during the winter months. Polar Biol 29:270-279

> Landau D, Dawson W (1970) The histology of retinas from the pinnipedia. Vision Res 10:691-702

Lea MA, Johnson D, Ream R, Sterling J, Melin S, Gelatt T (2009) Extreme weather events influence dispersal of naive northern fur seals. Biol Lett 5:252-257

> Moulton VD, Miller EH, Hugo OA (2000) Haulout behaviour of captive harp seals (Pagophilus groenlandicus): incidence, seasonality and relationship to weather. Appl Anim Behav Sci 65:367-378

> Mulaudzi TW, Hofmeyr GJG, Bester MN, Kirkman SP and others (2008) Haulout site selection by southern elephant seals at Marion Island. Afr Zool 43:25-33

Nordøy ES, Folkow L, Blix AS (2009) Distribution and diving behaviour of crabeater seals (Lobodon carcinophagus) off Queen Maud Land. Polar Biol 15:261-268

Noren SR, Pearson LE, Davis J, Trumble SJ, Kanatous SB (2008) Different thermoregulatory strategies in nearly weaned pup, yearling, and adult Weddell seal (Leptonychotes weddellii). Physiol Biochem Zool 81:868-879

> Patterson TA, Thomas L, Wilcox C, Ovaskainen O, Matthiopoulos J (2008) State-space models of individual animal movement. Trends Ecol Evol 23:87-94

Pütter A (1903) Die Augen der Wassersäugethiere. Zool Jahrb Abt Anat 17:99-399

Reder S, Lydersen C, Arnold W, Kovacs KM (2003) Haulout behaviour of high Arctic harbour seals (Phoca vitulina vitulina) in Svalbard, Norway. Polar Biol 27:6-16

Sato K, Yasutaka T, Kudoh S, Naito Y (2003) Meteorological factors affecting the number of Weddell seals hauling-out on the ice during the molting season at Syowa Station, East Antarctica. Polar Biosci 16:98-103

Schneider DC, Payne PM (1983) Factors affecting haul-out of harbor seals at a site in southeastern Massachusetts. J Mammal 64:518-520

Siniff DB, Tester JR, Kuechle VB (1971) Some observations on the activity patterns of Weddell seals as recorded by telemetry. Antarct Res Ser 18:173-180

Sjöberg M, Fedak MA, McConnell BJ (1995) Movements and diurnal behaviour patterns in a Baltic grey seal (Halichoerus grypus). Polar Biol 15:593-595

Smith MSR (1965) Seasonal movements of the Weddell seal in McMurdo Sound, Antarctica. J Wildl Manag 29: $464-470$

Stirling I (1969) Distribution and abundance of the Weddell seal in the western Ross Sea, Antarctica. NZ J Mar Freshw Res 3:191-200

Thomas JA, DeMaster DP (1982) An acoustic technique for determining diurnal activities in leopard (Hydrurga letponyx) and crabeater (Lobodon carcinophagus) seal. Can J Zool 60:2028-2031

Thomas JA, DeMaster DP (1983) Diel haul-out patterns of Weddell seal (Leptonychotes weddelli) females and their pups. Can J Zool 61:2084-2086

> Tougaard J, Teilmann J, Tougaard S (2008) Harbour seal spatial distribution estimated from Argos satellite telemetry: overcoming positioning errors. Endang Species Res 4:113-122

Trillmich F, Mohren W (1981) Effects of the lunar cycle on the Galapagos fur seal, Arctocephalus galapagoensis. Oecologia 48:85-92

Wheatley K, Bradshaw C, Davis L, Harcourt R, Hindell M (2006) Chemical immobilization of adult female Weddell seals with tiletamine and zolazepam: effects of age, condition and stage of lactation. BMC Vet Res 2:8. Available at www.biomedcentral.com/1746-6148/2/8

Submitted: April 30, 2009; Accepted: November 23, 2009

Proofs received from author(s): January 20, 2010 